\title{
INSTITUTIONAL ISSUES IN THE SITING OF LOW LEVEL RADIOACTIVE WASTE FACILITIES
}

\author{
Clark Prichard*
}

\section{Introduction}

The problem of disposal of low level radioactive waste is an acute one. These wastes are composed of a variety of items which are contaminated by low levels of radiation. Low level radioactive wastes are a by-product of nuclear power plant operations, medical and other research, medical treatment, and industrial processes. Existing sites for disposal of these wastes (there are now only three operating in the United States) are running short of capacity, and the states where they are located are becoming more averse to serving as dumping grounds for the entire nation's low level radioactive waste. ${ }^{1}$ To deal with the problems of finding additional disposal capacity, Congress passed the 1980 Low Level Radioactive Waste Policy Act. This law places responsibility for low level radioactive waste disposal on the states, and encourages states to form regional groupings (compacts) to jointly establish and operate regional disposal facilities. Although originally scheduled for start-up on January 1, 1986, additional time has been allotted for compact negotiations. When implemented the law will permit Congressionally approved regional compacts to ban shipments of out-of-region low level radioactive waste for disposal within the region. States are presently in the process of banding together to form regional compacts. This process is being carried out with some urgency as no state wants to be outside a compact group when the disposal ban takes effect."

At this time, it appears that from eight to twelve regional compacts will be formed. There is a great deal of negotiating underway between states, and membership in most compacts has not yet been finalized. The process of forming compacts has been slowed by dis-

*U.S. Nuclear Regulatory Commission. The views expressed here are solely the author's. I would like to acknowledge the help of Hays Gamble, Mike Kaltman, Steve Salomon, Bill Metz and John Stewart for reviewing this paper. agreements between prospective compact members over compact provisions for site selection, appropriate disposal methods, and compact management issues. Individual states may negotiate with several prospective compacts, seeking the most favorable terms available (such as a compact containing an already operating disposal facility).

Some compacts will have the luxury of containing an existing low level radioactive waste site, although even in these cases, plans are being made for a second, new site to be established within a given time frame. Selecting a site for a new disposal facility and getting it operational will be a difficult and timeconsuming process. While siting will be heavily influenced by geologic, climatic, and engineering factors, the General Accounting Office concludes that "the problems now associated with low level waste disposal are largely political, logistical, and institutional."s It is toward the institutional issues involved in low level radioactive waste siting that the focus of this paper is directed.

LOW LEVEL

RADIOACTIVE WASTE FACILITIES

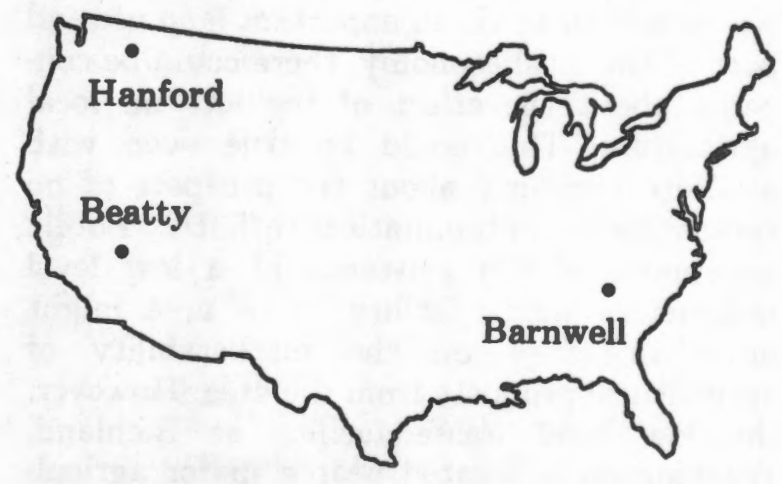

SOURCE: U.S. Department of Energy 


\section{Socioeconomic Impacts of an LLRW Facility}

Socioeconomic impacts of nuclear power plants can be quite varied and significant. A nuclear power plant is a huge construction project, employing thousands of construction workers for years. In addition, many plants produce huge tax revenues for local government.

However, in sharp contrast to these types of nuclear facilities, a low level radioactive waste disposal facility is a comparatively minor entity. There would be no huge construction work force and resultant influx of population. Since radiation levels of waste handled at such a facility would be relatively low, there would be no potential danger of a large-scale release of highly radioactive material associated with an accident. A low level radioactive waste facility would employ a hundred or so workers at most, occupy a few hundred acres of land, not involve major construction, and would not contribute property tax revenue to local government since the site must be either federal or state owned land.

There are some potential impacts which could be of concern to local residents. Truck traffic associated with a low level radioactive waste facility has been a concern at operating facilities. Since a low level radioactive disposal facility is likely to be located in a relatively rural area, the volume of truck traffic hauling waste to the site can be perceived as a significant additional strain on the local road network. In addition, truck noise could be a concern.

If a disposal site is proposed for an area where agriculture is an important land use and part of the local economy, there could be concerns about the effect of the site on local agriculture. This could be true even with absolute certainty about the prospect of no radioactive contamination offsite. Public awareness of the existence of a low level radioactive waste facility in an area might have an effect on the marketability of agricultural products from the area. However, the low level waste facility at Richland, Washington is located near a major agricultural area, and no problems of this type have arisen. The issue may, however, be raised as a cause of concern by local residents, who may see the need for assurances against this eventuality.

The impact of a low level radioactive waste site on propery values may also be an issue.
Local residents could be concerned that the existence of a radioactive waste facility nearby could have an adverse effect on the market value of their property. This issue is clearly a matter of perception, but perception can have an impact on market value. If the location of a low level radioactive waste facility nearby were a negative factor with potential buyers, the market value of property would be affected. Obviously, this is a difficult issue to evaluate. A study of residential property values near four nuclear power plant sites in the Northeast found no significant effect on property value due to nearness to the power plant. ${ }^{4} \mathrm{~A}$ study of property values near ten solid waste disposal sites in Pennsylvania did not reveal any significant adverse effect on property values. ${ }^{6}$

No comprehensive studies have yet been done on the property value effects of low level radioactive waste sites. Results from studies on other types of facilities, even ones with similar characteristics, cannot be assumed to apply to low level radioactive waste sites. However, it is relevant to note that the aforementioned studies found no significant impact on property values due to facilities which might be considered "undesirable" in the public mind.

\section{Financial Surety and Liability}

This issue dominates the controversy over the low level radioactive waste facility operating history of the United States. In several instances in the recent past, the premature closure of low level radioactive waste disposal sites has resulted in cleanup and other site decommissioning costs being borne by the public, rather than the site operators or waste generators. When commercial low level waste sites were developed, it was standard practice for states to require that funds be set aside to deal with decommissioning and post-closure maintenance. The funds so earmarked were designed to provide an adequate amount for the costs of shutdown and care required after the facility was closed. The assumptions generally underlying these estimates proved to be unfounded; costs escalated far in excess of forecasts, and in several cases, sites were closed after only a few years of operation, rather than the several decade operating lifetime which was planned. The latter condition resulted in the accumulation of 
only a small part of the total closure and maintenance fund. At the Sheffield, Illinois; Maxey Flats, Kentucky; and West Valley, New York sites, early closing of the site led to a substantial shortfall of funds available compared with those necessary for closure and long-term care. ${ }^{6}$ The burden of providing the needed financing fell on the host states in each case, to their obvious and immense displeasure.

These situations brought the issue of financial surety to a very high degree of public awareness and concern. Taxpayers in host or potential-host states wanted ironclad assurances that the siting of a low level radioactive waste facility would not bring on unforeseen financial burdens in future years. This general concern led to a provision in the 1982 Nuclear Waste Policy Act which requires the Nuclear Regulatory Commission to establish standards for financial surety and liability which would "permit completion of all requirements established by the Commission for the decontamination, decommissioning, site closure, and reclamation of sites, structures, and equipment used in conjunction with such low level radioactive waste." The Act also permits the Department of Energy to take custody of low level radioactive waste and closed waste disposal sites, upon request of the owner (presumably a state) if federal management is deemed to be "necessary or desirable to protect the public health and safety, and the environment."

The objective of this federal action is to set up a system where a disposal site operator must at all times maintain the financial means to properly clean up and close a low level radioactive waste site. As a last resort, DOE can take over a site if there is no other way that local authorities could avoid having the financial burden of cleanup placed on them.

\section{Economic Viability of Regional Compacts}

In normal circumstances, when a new economic entity such as a factory or distribution center is being planned, location is chosen after an exhaustive study of a multitude of factors. Availability of raw materials and other inputs, distance to major markets, availability and cost of labor, land, and utility services-all are very carefully considered. However, the selection of regional low level radioactive waste facility sites will not be made under normal circumstances. It is most likely that a combina- tion of geologic and political factors will be decisive in the selection of locations. Due to this probability, the economic viability of regional low level radioactive waste disposal facilities is cause for concern. By economic viability we mean the existence of sufficient resources from waste disposal operations to offset costs of siting, licensing and actual operation of the facility.

What the Congress has authorized, and what is being planned by the states, is a system of regional "markets" for low level radioactive waste disposal. Waste produced outside each region can be prohibited from disposal at facilities within the region a still to be determined date. A region may decide not to impose this prohibition, but at present, there appears to be strong political pressure to impose such a ban. If such a ban is actually imposed by all regions, then generators of low level waste within each region will have only one alternative-disposal in that particular region's facility or facilities should a region decide for more than one low level radioactive waste facility. Within each regional "market," the following economic factors will influence the economic viability of the facility.

The facility will have certain costs associated with site selection, land acquisition, licensing, facility planning and engineering, and site preparation and construction. It will also have variable costs associated with the actual disposal of given volumes of low level radioactive waste. The type of disposal method which is presently used is a shallow land burial, where actual disposal operations consist of trench excavation, preparation of the trenches to receive waste, capping the trench, and routine maintenance and monitoring. Estimates of costs are very uncertain at this time, but with substantial fixed costs, the average cost of disposal would diminish as the volume of waste disposed of increased. Therefore, the larger the volume of waste each site handled, the lower the fee charged to waste generators could be while ensuring the economic viability of the facility. Thus, the overall capacity for generating low level radioactive waste within each region is a crucial variable in determining the economic viability of the region's disposal site. If the volume of waste produced is too low, then the fee which would have to be charged for disposal would be prohibitive. Estimates of the fee, which would be necessary to operate an 
Table 1

Disposal Site Costs and Generator Prices ${ }^{a}$

\begin{tabular}{|c|c|c|c|c|c|}
\hline \multirow[b]{2}{*}{ Type Site } & \multirow[b]{2}{*}{$\begin{array}{l}\text { Site } \\
\text { Sized }\end{array}$} & \multicolumn{2}{|c|}{ Total Disposal Site Costs ${ }^{b}$} & \multicolumn{2}{|c|}{ Generator Price $^{c}$} \\
\hline & & $\begin{array}{c}\text { Public } \\
\text { Finmancing }\end{array}$ & $\begin{array}{l}\text { Private } \\
\text { Financing }\end{array}$ & $\begin{array}{c}\text { Public } \\
\text { Financing }\end{array}$ & $\begin{array}{c}\text { Private } \\
\text { Financing }\end{array}$ \\
\hline $\begin{array}{l}\text { Multiple } \\
\text { waste type }\end{array}$ & $\begin{array}{r}1,200 \\
500 \\
100\end{array}$ & $\begin{array}{r}121,400,000 \\
82,000,000 \\
50,600,000\end{array}$ & $\begin{array}{l}205,200,000 \\
147,800,000 \\
101,500,000\end{array}$ & $\begin{array}{r}3.40 \\
5.50 \\
16.90\end{array}$ & $\begin{array}{r}5.70 \\
9.90 \\
33.80\end{array}$ \\
\hline
\end{tabular}

a. Constant 1981 dollar values.

b. Development through the end of operating life, including the postoperational care fund.

c. Price given in dollars per cubic foot.

d. Annual capacity-thousands of cubic feet.

Source: U.S. Department of Energy, Directions of Low-Level Radioactive Waste Management: An Analysis of Low-Level Waste Disposal Facility and Transportation Costs, 1983.

economically viable facility, and the sensitivity of the fee to the volume of low level radioactive waste handled, have been compiled by the Department of Energy. The following table indicates that "generator fee" (the fee which would have to be charged to cover all costs and provide an adequate return on investment) falls sharply as volume increases.

Low level radioactive waste generators do have an alternative, and that is volume reduction. Volume reduction is basically a system which compacts the waste products, resulting in a drastically reduced volume of waste product. This has the potential of cost savings for a waste generator in two ways: (a) transportation charges for transporting the waste from the generator to the disposal site would be less, and (b) if disposal fees are based on volume, disposal costs would be cut. Depending on the actual cost savings to be realized, compared with the cost of acquiring and operating necessary volume reduction equipment, waste generators could opt for volume reduction, thus further reducing the volume of waste going to the disposal site.

The system of prohibiting shipments of waste from outside the regional compact group creates, in essence, a monopoly situation. A fundamental principle of economics is that the existence of a monopoly allows the holder of the monopoly considerable power over the market. In this case, the existence of only one source for the disposal of low level radioactive waste has the potential for allowing disposal fees to greatly exceed actual costs of disposal. Should waste generators conclude that the fees being charged were exorbitant, there would be strong pressure for the compact commission to set up a system of control over disposal charges. In other areas where a monopoly is allowed by law to exist, such as local telephone communications, electric and gas service, and water and sewer service, local authorities exercise control over prices charged. It would be in keeping with this tradition for regional compact commissions to have some degree of control over disposal fees. Were this to be the case, the same type of issues which arise in other controlled monopolies would likely surface. Disposal fees would have to be continually adjusted to allow for an equitable return on the operator's investment in the facility, while at the same time keeping disposal costs as low as possible for waste generators.

In the long run, these issues of quantity of waste generated within the region, extent of volume reduction practiced, and fees charged for disposal could make or break a regional compact group. If volume of waste available for disposal is too small, disposal fees may have to be set fairly high to recover costs. If the fees are significantly higher than those in neighboring regional groupings, there would be a natural tendency for waste generators to seek lowest cost disposal. There might be incentive for one or more states to break off from the compact group and join with other, lower cost compact groups. This may be impossible to do under compact rules, but wherever economic forces come into conflict with institutions, the potential for problems exists.

Up to this point, it seems that the process of 
compact formation has been essentially a political/institutional one. The economics of regional waste disposal facilities are certainly considered, but with a high degree of uncertainty as to actual facility operations and costs it is difficult to specify an "optimum" compact size. This leaves plenty of room for the many other considerations involved in the compacting process to hold sway.

\section{Community Acceptance}

The search for suitable sites for low level radioactive waste disposal facilities will be severely hampered, and very possibly stopped outright, by opposition from communities in the surrounding areas. The delaying tactics available to local communities which oppose a site are formidable enough to create substantial delays in schedules and make the costs of opening a new site prohibitive. Community acceptance is thus almost certainly a necessary condition for establishing a new low level radioactive waste disposal site. Virtually no one wants to solve the pressing national problem of low level radioactive waste disposal by forcing a site on an unwilling public. Yet, the winning of community acceptance is not likely to be an easy task. Adequate safeguards to the public health and safety and the protection of the environment are certainly the necessary first steps, and these are already in place. However, community acceptance requires more. The preceding sections have pointed out a number of non-health and safety issues which concern local communities; possible impacts on property values, worries about financial liability for closure and maintenance of sites, "nuisance" impacts such as increased truck traffic, and others. These "negatives" must either be adequately addressed on an individual basis, or outweighed by positive benefits which are derived from hosting a low level radioactive waste site.

Several approaches are possible. Some deal with alleviating local concerns directly. For example, traffic networks can be improved to allow more direct highway access to the site, relieving traffic congestion and truck noise problems. Others attempt to deal with problems in a more general way. The states of Washington and South Carolina presently levy a tax on low level radioactive waste shipped to disposal sites within the state; a portion of the tax revenues are returned to local jurisdictions in the vicinity of the site. This precedent is likely to be extended to newly-developed low level radioactive waste facilities in other states. The basic idea is a sound one-tax revenues from this source allow local communities to offset whatever negative impacts result from proximity to a low level waste site. The additional tax revenues permit expenditures for improved local services such as police and fire protection, educational systems, roads, etc., beyond what would be available without these additional tax revenues. They may also be used to lower local property taxes while keeping the level of services constant, or some combinations of the two. Residents in communities hosting a site can make their own decision on what benefits they wish to enjoy with funds derived from the site.

Whatever combinations of approaches are employed, they must, in sum, constitute a large enough "benefit" to tip the cost/benefit balance in the direction of a favorable local community view of the facility.

The arrangement whereby local communities are compensated for hosting a waste disposal facility can draw support from even the most rudimentary analysis of the incidence of costs and benefits. Society in general derives the benefits from disposal of its hazardous wastes. Host communities would be asked to bear the major burden of the costs associated with having a waste disposal facility located nearby. An equitable arrangement would have society compensate host communities for bearing these costs.

\section{FOOTNOTES}

\footnotetext{
'Regional Low Level Radioactive Waste Disposal Sites-Progress Being Made But New Sites Will Probably Not Be Ready By 1986, U.S. General Accounting Office, Washington, D.C., 1983, pg. 7.

'There is at least one exception-Texas has chosen to develop its own site.

U.S. General Accounting Office, op. cit. pg. 7.

"Gamble, Hays and Downing, Roger, "Effects of Nuclear Power Plants on Residential Property Values," Journal of Regional Science, Vol. 22, No. 4, 1982.

Gamble, Hays, Downing, Roger, Shortle, James and Epp, Donald, "Effects of Solid Waste Disposal Sites on Community Development and Residential Property Values," Institute for Research on Land and Water Resources, The Pennsylvania State University, 1982.

"Cohen, Linda, "Who Pays the Bill: Insuring Against the Risks from Low Level Nuclear Waste Disposal," Natural Resources Journal, 21, October, 1981.

'U.S. Congress, Nuclear Waste Policy Act of 1982, Subtitle D, "Financial Arrangements for Low Level Radioac-
} 
tive Waste Site Closure."

${ }^{8}$ ibid.

\section{REFERENCES}

Cohen, Linda, "Who Pays the Bill: Insuring Against the Risks From Low Level Nuclear Waste Disposal," Natural Resources Journal, No. 21, October, 1981.

Gamble, Hays and Downing, Roger, "Effects of Nuclear Power Plants on Residential Property Values," Jour nal of Regional Science, Vol. 22, No. 4, 1982.

Gamble, Hays; Downing, Roger; Shortle, James; and Epp, Donald, Effects of Solid Waste Disposal Sites on Com- munity Development and Residential Property Values, Institute for Research on Land and Water Resources, The Pennsylvania State University, 1982.

U.S. Congress, Nuclear Waste Policy Act of 1982 , Subtitle D, Financial Arrangements for Low Level Radioactive Waste Site Closure.

U.S. Department of Energy, Directions in Low-Level Radioactive Waste Management: An Analysis of LowLevel Waste Disposal Facility and Transportation Costs, 1983.

U.S. General Accounting Office, Regional Low-Level Radioactive Waste Disposal Sites-Progress Being Made But New Sites Will Probably Not Be Ready By 